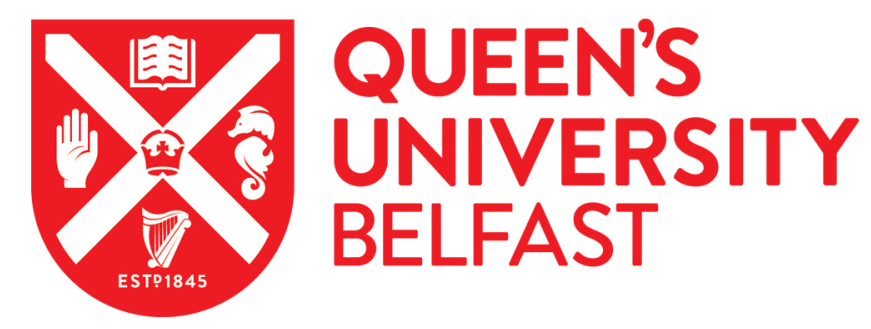

\title{
The Barry Urban District Council, disaster relief funds and civic society, 1913-1934
}

Foster, A-M. (2020). The Barry Urban District Council, disaster relief funds and civic society, 1913-1934. Urban History. https://doi.org/10.1017/S0963926820000577

\author{
Published in: \\ Urban History
}

Document Version:

Peer reviewed version

Queen's University Belfast - Research Portal:

Link to publication record in Queen's University Belfast Research Portal

Publisher rights

(C) 2020 Cambridge University Press.

This work is made available online in accordance with the publisher's policies. Please refer to any applicable terms of use of the publisher.

\section{General rights}

Copyright for the publications made accessible via the Queen's University Belfast Research Portal is retained by the author(s) and / or other copyright owners and it is a condition of accessing these publications that users recognise and abide by the legal requirements associated with these rights.

Take down policy

The Research Portal is Queen's institutional repository that provides access to Queen's research output. Every effort has been made to ensure that content in the Research Portal does not infringe any person's rights, or applicable UK laws. If you discover content in the Research Portal that you believe breaches copyright or violates any law, please contact openaccess@qub.ac.uk. 
The Barry Urban District Council, disaster relief funds and civic society, 1913-34

The early twentieth century witnessed some of the worst mining disasters the UK has ever seen. Towns and cities leapt to the aid of bereaved families, raising tens of thousands of pounds in aid. Yet, while the effects of disaster funds on the locality in which they were administered have been the focus of scholarly work, little attention has been given to how these funds were created in constituencies outside of the disaster zone. The Barry Urban District Council (UDC) responded to the call for help after the Senghenydd (1913) and Gresford (1934) disasters, opening relief funds to aid the affected. The funds blurred the line between charity and local government, with the Barry UDC reliant on functions of civic society to aid its philanthropic turn. Their reaction offers insights into the charitable role of UDCs, reflecting on how they used these opportunities to further civic activity.

Keywords: Disaster, Charity, local government

In 1913, the small Welsh mining village of Senghenydd became the location of the worst mining disaster in Britain, when an explosion resulted in the deaths of 440 men and boys. Over twenty years later, Wales was once again the site of tragedy when, in 1934, in the North of the country, a disaster at the Gresford Colliery in Wrexham resulted in the death of 266 men and boys. These two explosions would mark the highest death tolls from mining disasters in twentieth century Wales. Newspapers chronicled the disasters, labelling those who attempted to rescue their fellow workers heroes, describing the damage wrought by the blasts, and recording particularly traumatic cases of family loss. Postcards and ephemera further captured these dramatic events, spreading visual news of the disasters across the nation. The public responded in a swift and practical way, through collecting money to aid the immediate suffering of victims and their families. Towns and cities leapt to assist the affected, organizing collections and raising tens of thousands of pounds for those in need. These funds were crucial to the wellbeing of the victims' families. Despite the gradual merger of state and charity in the interwar period, there was no national fund to assist those who were affected 
by sudden disaster. These charitable funds, raised by the public, often formed the majority of financial assistance that those affected by disaster could appeal to for help.

While there has been a robust body of scholarship examining the effects of disaster funds on the locality in which they were administered, little attention has been given to how these funds were created in constituencies outside of the disaster zone. ${ }^{1}$ Yet, these external areas, unaffected by disaster, comprise the majority of constituencies who were involved in initiatives to provide immediate relief for those affected. The Barry Urban District Council (UDC) was one of multiple District Councils which attempted to focus fundraising for disaster victims within their local area. The reaction of the Barry UDC to the Senghenydd and Gresford disasters is significant, as it offers a way to examine the shifting nature of local government through the lens of charitable assistance in the early twentieth century.

The UDCs participated in these external fundraising initiatives during a period where their power over the local area was waning, and so these funds acted as a way of marking ownership over civic space. In Britain, by the 1930s, local governments oversaw a rich array of local services, which were subsumed into central powers following the Second World War. ${ }^{2}$ Compared to other UDCs in the 1930s, UDCs in South Wales showed a remarkable amount of autonomy during the interwar period. ${ }^{3}$ Nationally, as their powers were rescinding, local governments consolidated their control over civic space. ${ }^{4}$ Barry, as a town established in the

\footnotetext{
${ }^{1}$ See, for example, the excellent case study of charity given to Londoners after the Great Fire by J. Field, 'Charitable giving and its distribution to Londoners after the Great Fire, 1666-1676', Urban History, 38 (2011), 323. Also see work on the aid distributed in Lancashire after the Cotton Famine: P. Shapley, 'Urban charity, class relations and social cohesion: charitable responses to the Cotton Famine', Urban History, 28 (2001), 46-64; L. Kiesling, 'The long road to recovery: postcrisis coordination of private charity and public relief in Victorian Lancashire', Social Science History, 21 (1997), 219-43.

2 J. Garrard and M. Goldsmith, 'Municipal progress and decline since 1835', The International Journal of Regional and Local Studies, 7 (2013), 41-2.

${ }^{3}$ C. Williams, 'Labour and the Challenge of Local Government, 1919-1939', in D. Tanner, C. Williams and D. Hopkin (eds.), The Labour Party in Wales 1900-2000 (Cardiff, 2000), 141.

${ }^{4}$ R.H. Trainor, 'The 'decline' of British urban governance since 1850', in R.J. Morris and R.H. Trainor (eds.), Urban Governance: Britain and Beyond since 1750 (Aldershot, 2000), p. 37; B. Doyle and A. McElligott, 'The rise and fall of European municipal power since 1800', The International Journal of Regional and Local Studies, 7 (2013), 11.
} 
late nineteenth century, married a clear sense of localism with the urgency of creating a strong identity as an area formed by the South Wales coalfield but not of it. ${ }^{5}$ The Barry UDC relief funds played on conceptions of localism and, through fundraising initiatives, expressed a strong sense of regional and urban identity, shifting from an appeal to the county in 1913, to civic duty towards the town in 1934.

The creation of UDC funds were an intervention into what had previously been the locus of civic society. As Graeme Morton argues, 'the voluntary organisation was the heart of civic society and it gave the state something tangible to enshrine. ${ }^{6}$ It has been well established that by the early twentieth century the boundary between the state and civic society was decidedly porous. ${ }^{7}$ The intermingling of state imposed assistance, through the Workmen's Compensation Acts, with that of private charity, is representative of the 'mixed economy of welfare' present in the interwar period. ${ }^{8}$ This 'mixed economy' had its roots in the first decade of the twentieth century, where the implementation of Liberal social legislation, and the creation of the proto-welfare state, led to an increasing recognition of the value of charitable services as complementary to government provision. ${ }^{9}$ The First World War consolidated this reciprocal relationship. Peter Grant argues that the war acted as a catalyst for this developing mutual interest, with the sheer amount of aid generated during the conflict leading to an increasingly professionalized charitable sector, which in turn increasingly appealed to the

\footnotetext{
5 P. Stead, 'The town that had come of Age: Barry 1918-1939', in D. Moore (ed.), Barry: The Centenary Book (Barry Island, 1985), 368.

${ }^{6} \mathrm{G}$. Morton, 'Civil society, municipal government and the state: enshrinement, empowerment and legitimacy. Scotland, 1800-1929', Urban History, 25 (1998), 353.

7 R.J. Morris, 'Governance: two centuries of urban growth', in R.J. Morris and R.H. Trainor (eds.), Urban Governance: Britain and Beyond since 1750 (Aldershot, 2000), 1.

${ }^{8}$ The phrase was originally coined in G. Finlayson, 'A moving frontier: voluntarism and the state in British social welfare 1911-1949', Twentieth Century British History, 1 (1990), 202; also see P. Thane, The Foundations of the Welfare State (Cambridge, 2008), 143. For a description of its historiographical use see P. Thane, 'The 'Big State' versus the 'Big Society' in twentieth-century Britain', in C. Williams and A. Edwards (eds.), The Art of the Possible: Politics and governance in modern British history, 1885-1997: essays in memory of Duncan Tanner (Manchester, 2015), 34.

${ }^{9}$ F. Prochaska, The Voluntary Impulse (London, 1988), 72; 82; M.J. Moore, 'Social service and social legislation in Edwardian England: the beginning of a new role for philanthropy', Albion, 3 (1971), 37.
} 
state. ${ }^{10}$ As a direct result of the war, the National Council of Social Service was established in 1919, to reduce duplication of charities and work with developing statutory bodies, further linking the two. ${ }^{11}$ During the interwar period, the two sectors continued to merge, falling into the pattern of charitable organisations identifying social needs and appealing to the state for assistance in meeting them. ${ }^{12}$

In practice, this merger of the state and the voluntary sector was enacted at a local level. During the interwar period, charities and local governments worked in tandem to deliver child protection services and education initiatives. ${ }^{13}$ Increasingly the two relied on each other for long-term social care, however, these extended charitable connections between local government and voluntary bodies were different in nature to the phenomenon explored here. The Barry funds were not an example of local government working with charities to provide a local service, but instead the UDC explicitly raised money and organized volunteers to meet a wider societal needs. Local government directly intervened in the charitable sector, using the mechanisms of civic society to appeal to those in its locale. Whilst this was a subtle shift, it represents the growing power of the UDC over its civic space, and indicates that local authorities felt comfortable extending their powers into this area of charitable activity at times of perceived need.

\section{Charity and disaster}

Through these disaster-based fundraising initiatives, local authorities were engaging in an area of philanthropic activity which had a long and established history, which ranged well

\footnotetext{
${ }^{10}$ P. Grant, Philanthropy and Voluntary Action in the First World War: mobilizing charity (London, 2014), 168172.

${ }^{11}$ Finlayson, 'A moving frontier', 202.

12 Thane, 'The 'Big State' versus the 'Big Society', 35.

${ }^{13}$ B. Doyle, 'The changing functions of urban government: councillors, officials and pressure groups', in M. Daunton (ed.), The Cambridge Urban History of Britain, Vol III (Cambridge, 2000), 311. For a discussion of this in relation to the South Wales coalfield see S. Thompson, 'Varieties of Voluntarism in the South Wales Coalfield, c.1880-1948' in C. Rochester, G.C. Gosling, A. Penn, and M. Zimmeck (eds.), Understanding the Roots of Voluntary Action: historical perspectives on current social policy (Brighton, 2011), 82-94.
} 
beyond the boundaries of industrial accidents. Jacob Field has shown that the recovery of cities after fires in the early modern period was often only possible because of external financial aid, raised through charitable collections which appealed to the nation for assistance. ${ }^{14}$ In the industrial sphere, while there were a limited amount of major mining disasters before the nineteenth century, as pits got deeper, and therefore progressively more dangerous, public subscriptions following large mining disasters became increasingly common. ${ }^{15}$ Public generosity in times of crisis was strong throughout the latter half of the nineteenth century, influenced by notions of philanthropic morality which characterized late Victorian society. As Frank Prochaska noted, during the late nineteenth century, '[with]in the familiarity of the community, whether rural or urban, benevolence was a moral obligation, if not a test of faith. ${ }^{\prime 16}$ These charitable feelings did not leave the populace at the turn of the century, and throughout the early twentieth century charitable giving proved a highly popular civic activity. ${ }^{17}$ Mining communities in particular were aware of the need to donate money after colliery disasters and workers sometimes voluntarily levied their wages to aid fellow workers after tragedy struck. Following the 1909 West Stanley colliery explosion, the workers of the Urpeth Colliery ' $\mathrm{s}$ ' Pit donated 1s per man and 6d per boy from their wage packets to the families of the victims. ${ }^{18}$ Not only did charitable giving act as a marker of faith, or civic duty, but as an expression of solidarity among groups of workers.

The families of those who died in industrial accidents were financially reliant on a mixture of state funds and private charity and, for the victims of disaster, charitable funds constituted at least half of the income they could hope to receive in the weeks and months following the tragedy. Following the 1897 Workman's Compensation Act, employers were required to provide compensation for employees killed at work. ${ }^{19}$ Pay outs from this source were married with grants from charitable funds to support those who had lost their primary wage earner.

\footnotetext{
${ }^{14}$ Field, 'Charitable giving and its distribution to Londoners', 5.

15 J. Benson, 'Colliery disaster funds, 1860-1897', International Review of Social History, 19 (1974), 73-6.

${ }^{16}$ Prochaska, The Voluntary Impulse, 41.

${ }^{17}$ G. Finlayson, Citizen, State, and Social Welfare in Britain (Oxford, 1994), 129-35; 238.

${ }^{18}$ Durham Chronicle (DC), 12 March 1909, 7.

19 J. Benson, 'English coal-miner's trade-union accident funds, 1850-1900', Economic History Review, 28 (1975), 402.
} 
After pit disasters, even with the assistance of charities, the families of the victims were often financially disadvantaged compared to if their primary wage-earner had lived. ${ }^{20}$ This was a result of a deliberate policy of impoverishment by the administrators of both charity and state funds. The administrators of the Gresford fund were particularly vocal in claiming that the families of the deceased were not to be in an advantageous financial position, and that the death of their loved one would not be met with a sudden windfall. ${ }^{21}$

Disaster funds, raised by public subscription, were generally siphoned into a central fund and administered by a controlling body. Generally, grants were paid in weekly instalments to an injured man or the family of the deceased. Both the Senghenydd and Gresford funds were eventually centralized and administered through the locality in which the disaster occurred. This was not necessarily a straightforward process; after the Gresford disaster, the charitable relief funds were consolidated into two major funds: the Lord Lieutenant of Denbighshire's and the Lord Mayor of London's, which were consolidated into one major fund in 1935 . The majority of widows of Senghenydd miners were granted $£ 300$ from workers' compensation funds, paid in weekly instalments, in addition to a weekly amount from the disaster fund, which varied from $3 d$ to $10 d$, with a little extra for each dependent child. ${ }^{22}$ Money from the Gresford funds were similarly distributed, at an approximate rate of 10 s for widows; 6 s for children under $14 ; 10$ s for the first orphan from a family, 6 s for each subsequent child; and $7 \mathrm{~s}$ $6 \mathrm{~d}$ for a single dependent parent, or $10 \mathrm{~s}$ for two. ${ }^{23}$ In addition to supporting the families of the victims, both funds gave temporary allowances to those who had been made unemployed by the explosions.

These funds were administrated by a committee formed of people of some local importance, who had experience with local government, or who administered other charitable funds in some capacity. Given the elite role of these individuals within local society, they often

\footnotetext{
${ }^{20}$ Benson, 'Colliery disaster funds', 73.

${ }^{21}$ S. Williamson, Gresford: The Anatomy of a Disaster (Liverpool, 1999), 54-7.

${ }^{22}$ C. Welsby, "Warning as to her future behaviour": the lives of the widows of the Senghenydd mining disaster of 1913', Llafur, 6 (1995), 95-6.

${ }^{23}$ Williamson, Gresford, 54.
} 
perpetuated the idea of charity as a basic, almost punitive measure, which would, if too generous, disincentivize people to work. ${ }^{24}$ In consideration of this, not only were meagre amounts paid to those in need, but the guardians of the funds ensured that it was difficult for individuals to access the money collected. Catherine Welsby has highlighted the often gendered dimension to this, detailing the difficulties that the women of Senghenydd faced in obtaining financial assistance. Administrators attached moralistic conditions to the reception of assistance. In order to access the Senghenydd relief fund, women had to provide a marriage certificate, which was not always possible, and illegitimate children from cohabiting couples were given a paltry allowance compared to those born to married parents. Regular stipends could be stopped if the executive committee judged that women were performing immoral acts', loosely defined. ${ }^{25}$ Similar, morally-coded, restraints were put on the benefactors of the Gresford fund. If a widow remarried, access to the fund was void, as it was assumed that her new husband would financially care for his new wife. ${ }^{26}$

Fundraising methods remained remarkably stable throughout the nineteenth and early twentieth centuries, and bazaars, charity dances and collections were common ways of raising funds. ${ }^{27}$ These varied methods of fundraising were employed at both a local and national level. Nationally, Mansion House funds, opened by the Lord Mayor of London, collected vast sums for those in need. Historically, Mansion House Funds were opened after major disasters, such as the Lancashire Cotton Famine (1861-5), the Oaks Colliery disaster (1866), the sinking of the Empress of Ireland (1914), with some occasionally established after disasters in other countries, such as an earthquake in Japan in $1923 .{ }^{28}$ Locally, individual town and city councils could establish funds, and smaller groups, including churches and societies, often organized their own fundraising activities. Taken collectively, these actions led to an

\footnotetext{
24 Ibid.

${ }^{25}$ Welsby, 'Warning as to her future behaviour', 97-8; 104-5.

${ }^{26}$ Williamson, Gresford, 57-8.

27 Prochaska, The Voluntary Impulse, 60; C. Hindson, "'Gratuitous assistance'? the West End theatre industry, late Victorian charity, and patterns of theatrical fundraising', New Theatre Quarterly, 30 (2014), 17-28; Charitable sporting matches were also common, see J. Kay \& W. Vamplew, 'Beyond altruism: British football and charity, 1877-1914', Soccer \& Society, 11 (2010), 181-197.

${ }^{28}$ The Times (TT), 30 Aug 1862, 7; 22 Dec 1866, 3; 6 Jul 1914, 4; 5 Sep 1923, 4.
} 
outpouring of assistance, although collections after disaster were characterized by their haphazard nature. Geographically, events often overlapped, and different funds vied for the attention of locals, causing tension among fundraising groups.

Following the Senghenydd and Gresford disasters, there was an outpouring of charitable assistance from concerned members of the public. Mansion House funds were opened after both disasters, and local authorities in the areas affected by the disasters opened significant funds, which acted as the administrators of the final fund. After the 1913 Senghenydd disaster, notable large collections were raised by the Miners' Federation, the Lord Mayor of Cardiff, local authorities, newspapers, churches and various societies. ${ }^{29}$ Similar funds were established after the Gresford disaster in 1934 with large collections organized by the Mayor of Wrexham, the Daily Mirror and a multitude of local government collections. ${ }^{30}$ Given the amount of assistance, the Barry fund perhaps seemed unnecessary, however, as a town which sought to proclaim its urban identity, the Barry UDC rose to the challenge, formed a subcommittee, and entered into this milieu of charitable funds.

\section{The Barry Urban District Council relief funds}

The town of Barry was a relatively new one at the time of the first disaster collection: Royal Assent had been given for the Barry Dock and Railways Bill in 1884, and the houses built for rail and port workers became the basis of this new urban space. The population in the area rose swiftly, from 500 in 1881 to 33,763 in 1911, and by 1914 the town that sprung up to support this steep rise in population was reasonably well established. ${ }^{31}$ The two disasters occurred at the height of Barry's financial success and within the depths of the economic depression which gripped the industry-heavy South Wales. Barry was created to act as a port town, with direct rail links to the South Wales coalfield and by 1913 had outstripped all other

\footnotetext{
29 J.B. Philips, Senghenydd: A Brave Community (Abertillery, 2002), 164; J.H. Brown, The Valley of the Shadow (Port Talbot, 2009), 145; M. Lieven, The Universal Pit Village 1890-1930 (Llandysul, 1994), 251.

${ }^{30}$ Williamson, Gresford, 53.

${ }^{31}$ B.C. Luxton, 'Ambition, vice and virtue: social life, 1884-1914', in D. Moore (ed.), Barry: The Centenary Book (Barry Island, 1985), 272; R.W. Thomas, 'The building of Barry' 1914', in D. Moore (ed.), Barry: The Centenary Book (Barry Island, 1985), 335-350.
} 
ports in Wales in the tonnage of coal exported. ${ }^{32}$ Tied to coal as the town's economy was, the depression of the 1930s severely affected its residents. ${ }^{33}$ In 1933, approximately 40 per cent of the workforce in Barry were unemployed, and those who were in employment faced abnormally low wages. ${ }^{34}$ Yet this did little to impede the charitably-minded residents of the town. Nationally, the depression did little to stifle the philanthropic tendency among members of the public, with public donations to charities substantially increasing during the interwar years. ${ }^{35}$ Despite the hardships that Barry's residents faced, their philanthropic tendencies were largely in line with national efforts, and the effects of the depression were mentioned only once in 1934 , in a committee circular sent to those who had aided in the house-to-house collection, which simply noted that 'considering present economic conditions the sum collected has been most gratifying. ${ }^{36}$

The Barry UDC acted as the focal point for town fundraising initiatives in 1913 and 1934, creating sub-committees to deal with the new administrative challenge. Following the 1894 Local Government Act, the newly-formed Barry UDC returned 21 Councillors from the seven wards within the town. The political composition of the UDC was ambiguous. While neither the 1913 or the 1934 UDC fully succumbed to a Labour majority, moving from a Lib-Lab set of Councillors with strong Independent control, to a strong Labour minority with a weak Independent majority, the representation of Labour in the UDC steadily grew throughout the period. ${ }^{37}$ In the 1930s, Independent candidates on the UDC remained a mixture of people whose ideology ranged from Conservative, to Liberal, along with some genuinely Independent

\footnotetext{
32 K.O. Morgan, Rebirth of a Nation (Oxford, 2002), 126.

${ }^{33}$ B. Supple, The History of the British Coal Industry Vol 4 1913-1946 (Oxford, 1987), 278.

${ }^{34}$ Stead, 'The town that had come of Age', 402; 404.

35 B. Harris, The Origins of the British Welfare State: Social Welfare in England and Wales, 1800-1945 (Basingstoke, 2004), 187-9; J. Gardiner, "Searching for the gleam': finding solutions to the political and social problems of 1930s Britain', History Workshop Journal, 71 (2011), 104.

${ }^{36}$ Glamorgan Archives (GA), Borough of Barry Clerk Gresford Colliery Disaster Files (BB/C/8/5) Circular, 27 Oct. 1934.

${ }^{37}$ C. Williams, Capitalism, Community and Conflict: the South Wales coalfield 1898-1947 (Cardiff, 1998), 53; Stead, 'The Town That had Come of Age', 392; 414. For an overview of the Labour party's development across the South Wales coalfield see D. Leeworthy, Labour Country: political radicalism and social democracy in South Wales 1831-1985 (Cardigan, 2018).
} 
Councillors. ${ }^{38}$ The UDC was split into several sub-committees which dealt with various local issues, and following the Senghenydd and Gresford disasters, new sub-committees were formed to steer fundraising activities.

The Barry UDC relief fund committees used simple fundraising methods to ensure a wide range of people with varying financial means had the opportunity to donate. Both the 1913 and the 1934 committee decided that a house-to-house collection and a fundraising concert would be the primary means of fundraising in Barry, with committees established to organize the two different activities. The composition of the Barry UDC relief fund committees was similar to that of a voluntary body in the early twentieth century. The majority of the committee members were men, with a smattering of women to help organize the collections. Mirroring wider patterns among other charitable initiatives established in the wake of sudden disaster, such as the Lord Mayors' funds, the resident Council Chairman was appointed as the Chair of the UDC relief fund committee. In some committee paperwork, the relief fund was dubbed the 'Chairman's Fund', directly copying the nomenclature of ownership seen in larger city based and national funds.

The house-to-house collections were popular, with the 1913 house-to-house collection raising $f 8319 \mathrm{~s} 1 \mathrm{~d}$, rising to $f 1361 \mathrm{~s} 1 \mathrm{~d}$ in $1934 .{ }^{39}$ Despite the popularity of the house-tohouse collections, variety performances were key to both fundraising campaigns. The concerts featured local acts and were widely advertised. ${ }^{40}$ The 1913 concert featured a number of local groups, including two children's' choirs, as well as more established musicians, such as Professor Tom Jones, a local pianist, who was billed as a 'Triple Medallist, Diploma London Academy of Music, etc., etc. ${ }^{41}$ The 1934 concert featured The Virginia Minstrels, the Super Five Concert Party and various other local celebrities such as 'Master Ralph Jack, the Boy Wonder'. ${ }^{42}$ Tickets were sold at various prices to ensure that people from

\footnotetext{
38 Ibid., 410.

39 GA, Borough of Barry Clerk Senghenydd Colliery Disaster Files (BB/C/241). House to House Collection Accounts, 1913; BB/C/8/55. House-to-House Collection.

${ }^{40}$ Barry Dock News (BDN), 14 Nov. 1913, 6.

${ }^{41} \mathrm{GA} / \mathrm{BB} / \mathrm{C} / 241$. Barry Relief Fund Concert Programme.

${ }^{42} \mathrm{GA} / \mathrm{BB} / \mathrm{C} / 8 / 55$. Variety Concert Programme, 26 Oct. 1934.
} 
different socioeconomic backgrounds could support the fund and enjoy the entertainment on offer. This strategy was clearly successful, with the residents of Barry raising a total of $£ 506$ 4s $2 d$ in 1913 , and $f 617$ 6s $9 d$ in $1934 .{ }^{43}$ The 1913 fund was directly siphoned into the centralized Senghenydd fund, run by local authorities in the Valleys, and proceeds from the 1934 fund were sent to the Western Mail, which was in turn subsumed into the larger Wrexham fund.

\section{Urban District Council relief funds, localism and civic society}

The Barry UDC relief fund committee heavily relied on the civic-mindedness of the local population throughout its fundraising initiatives. Volunteers were necessary to help run the committee, organize house-to-house collections and give their time to organize the variety shows. Yet, the task of organizing the relief funds was not without some difficulty. Volunteers were not always satisfied with the committee's actions, and the UDC struggled to persuade businesses to donate to their fund, instead of the larger ones based in Swansea or Cardiff. Acknowledging the nature of civic planning, there was a democratization of the relief funds over time: in 1913 the committee only asked select people to be involved, but by 1934 there were town meetings and representatives of various local groups were invited to participate. This mirrored the changing expectations of the UDC. These snapshots of reactions to disaster, taken twenty one years apart, suggest the development of the Barry UDC from an organisation establishing its place in a thriving, but new, town, versus a mature UDC that knew how to appeal to the civic minded population.

The origins of the Barry funds are significant in realising the expectations placed on the UDCS by the 1930s. While the genesis of the 1913 Barry UDC disaster fund is unknown, likely being a mixture of local pressure and the interests of the Council, by the 1930s it was expected that town representatives would establish a collection for those in need. In 1934, the Barry UDC received a circular from the Gresford Colliery Disaster relief fund:

\footnotetext{
${ }^{43}$ GA/BB/C/241. BUDCRF to Lord Mayor of Cardiff, 12 Dec. 1913; R. J. Webber to BUDCRF, 5 Dec. 1934.
} 
Although we find from newspaper reports that a large number of Borough, Urban and Rural Councils in the country have taken action in organising appeals and collections for the benefit of the Fund, we venture to address this letter to all Authorities requesting co-operation in making the Fund as large as possible... The need for a substantial Fund is very great and we trust that we may appeal to your Council to organise collections in your area. ${ }^{44}$

It is significant that the Wrexham fund organizers felt that appealing to local urban, rural and municipal authorities was an important strategy in gaining national aid. The call for assistance through local government powers is indicative of the perceived local influence and organizational strength of the UDCs in the mid-1930s. Married with a shaming tactic, in noting that many had already independently decided to establish a relief fund, reluctant UDCs were spurred into action.

In Barry, calls for the establishment of a local fund were not just coming from other local authorities, but from other groups inside the town. Given the increasing interaction between local government and trade unions in the interwar period, it is unsurprising that the Barry \& District Trades Union Council asked the UDC to help establish a local fund. Trade unions were used to dealing with the mechanisms of local government, and were able to appeal to the UDC directly. ${ }^{45}$ The Barry \& District Trade Union suggested that the Council 'should be empowered to convene a meeting of the Religious, Political, and Social organisations of the town' and that 'it should immediately be made known that there would be one fund for the town of Barry. ${ }^{46}$ They offered their experience, having organized a collection for Lancashire cotton workers, concluding that they were 'prepared to place at your disposal the assistance of the Trade Union machinery, and the valuable experience obtained in similar efforts of this nature', concluding 'there will be no lack of willing, voluntary helpers. ${ }^{.47}$

\footnotetext{
${ }^{44} \mathrm{GA} / \mathrm{BB} / \mathrm{C} / 8 / 55$. Wrexham (Gresford) Colliery Disaster Relief Fund to Barry Urban District Council Relief Fund (BUDCRF), 29 Sept. 1934.

${ }^{45}$ Doyle, 'The changing functions of urban government', 309.

${ }^{46} \mathrm{GA} / \mathrm{BB} / \mathrm{C} / 8 / 55$. Barry \& District Trades Union Council to BUDCRF, 1 Oct. 1934.

${ }^{47} \mathrm{lbid}$.
} 
Internal pressure from residents and trade unions, along with external pressure from the Gresford funds and the newspaper lists of UDCs, spurred the Barry UDC into action, and it called for a meeting to discuss the possibility of opening a fund in early October 1934, nearly two weeks after the disaster. When inviting representatives to the meeting, the Council seemed unsure as to whether it would open a relief fund or not, stating that one would only be opened if all at the meeting agreed, concluding, 'if it is decided to raise a Fund, it will be necessary to take steps forthwith', a nod to the late reaction of Barry to the disaster. ${ }^{48}$ This hesitancy of the Barry UDC to organize a fund without support from local groups suggests that the UDC was aware of the difficulties of establishing a fund in Barry, given the amount of local fundraising already occurring, and the lateness of this meeting compared to other, more reactionary, fundraising activities.

In 1913, the organization of the fund was left to committee members only, seemingly without external consultation with the residents of Barry, by 1934, however, the UDC presented itself as an organization comfortable in its own urban space, willing to extend its reach to others as an organizational facilitator at a time of need. In 1934 the Barry UDC ensured that various groups within the town, as well as the town's urban spaces, were involved in their activities. The initial meeting for the 1934 committee was held in the Public Library, which was opened in 1906 as part of the Council's attempts to turn Barry into a thriving town. ${ }^{49}$ The meeting was open to all religious, social and political organizations in Barry and letters were sent to ensure that representatives were in attendance..$^{50}$ This willingness to involve notable local groups shows a mature UDC comfortable in its role as a facilitator for local affairs.

The gradual professionalization of the committee, and its emergence within a mature UDC, is hinted at through the commission of printed ephemera. The 1913 and the 1934 UDCs ensured that fundraising concerts were well advertised. In 1913, colourful posters were pasted around Barry, and 3,000 handbills advertised the event to dock workers. ${ }^{51}$ Despite the committee

\footnotetext{
${ }^{48} \mathrm{GA} / \mathrm{BB} / \mathrm{C} / 8 / 55$. Internal memo, 3 Oct. 1934.

49 Luxton, 'Ambition, Vice and Virtue: Social Life, 1884-1914', 286.

${ }^{50} \mathrm{GA} / \mathrm{BB} / \mathrm{C} / 8 / 55$. Internal Memo, 3 Oct. 1934.

${ }^{51} \mathrm{GA} / \mathrm{BB} / \mathrm{C} / 241$. Poster; Committee meeting minutes, 10 Nov. 1913.
} 
resolving to ask the printers to produce tickets and posters free of charge, the Senghenydd Relief Fund spent $f 3$ 17s on envelopes, slips and tickets, which were printed by the commercial stationers Barry Herald Co. and $£ 102 \mathrm{~s} 9 \mathrm{~d}$ for printing by W.H. Waite. ${ }^{52}$ Similarly, the Barry Dock News Printing \& Publishing Works charged $f 45 \mathrm{~s}$ for the printing of Senghenydd Relief Fund emblazoned ephemera; however, they printed programmes for free..$^{53}$

The 1934 committee formed a sub-committee to 'deal with all matters of advertising and publicity in connection with the Entertainment' and decided to hire a billposter to paste 250 posters advertising the performance to the residents of Barry. ${ }^{54}$ The 1934 committee commissioned printed ephemera from town printers in a way which did not favour any of the companies working in Barry. It commissioned 9,300 envelopes to be printed in total; 2,400 by E. J. \& I. J. Lewellin Printers, Bookbinders and Stationers; 2,300 by Brook and Williams, Printers, Bookbinders, \& c.; 2,300 by the Barry \& District News and 2,300 by the Barry Herald, which had printed ephemera for the fundraising committee in the wake of the Senghenydd disaster. ${ }^{55}$ In 1934 the committee paid the Barry Herald Ltd $£ 1$ 1s for 2,000 tickets printed for the variety performance, the Barry \& District News asked for $£ 16 s 6 \mathrm{~d}$ to cover the cost of printing the programmes and the Barry Advertiser Limited was given $f 1$ for printing 5,000 leaflets advertising the concert. ${ }^{56}$ The 1934 committee, far more so than their 1913 counterparts, showed a commitment to equally spreading printing contracts throughout

\footnotetext{
${ }^{52} \mathrm{GA} / \mathrm{BB} / \mathrm{C} / 241$. Committee meeting minutes, 29 Oct. 1913; Barry Herald Co. to BUDCRF, Dec. 1913; BUDCRF to W.H. Waite, 12 Dec. 1913.

${ }^{53}$ GA/BB/C/241. 'Barry Dock News' Printing \& Publishing Works to BUDCRF, 11 Dec. 1913; Concert Programme.

${ }^{54}$ GA/BB/C/8/55. BUDC Concert Committee Minutes, 12 Oct. 1934, 2; Bills, 26 Oct. 1934; Statement of Accounts; Route Taken by Billposter; Concert Committee Meeting Minutes, 15 Oct.; 25 Oct. 1934.

${ }^{55}$ GA, BB/C/8/55. Barry \& District News to BUDCRF, 31 Oct. 1934; E. J. \& I. J. Llewellin to BUDCRF, Oct. 1934; Barry Herald Limited to BUDCRF, Oct. 1934; Brook \& Williams to BUDCRF, 24 Oct. 1934. E. J. \& I. J. Llewellin charged 17s 6d; The Barry \& District News charged 17s 6d; Brook \& Williams charged 17d; and the Barry Herald Limited charged $17 \mathrm{~s} 6 \mathrm{~d}$.

${ }^{56}$ GA/BB/C/8/55. Barry Herald Ltd to BUDCRF, 29 Oct. 1934; Barry \& District News to BUDCRF, 24 Oct. 1934; Barry Advertiser Limited to BUDCRF, 27 Oct. 1934.
} 
Barry firms, showing a high level of care not to indicate favouritism, and ensuring that all were satisfied with UDC spending on local services.

The UDC had no slush fund to pay for the ephemera from, and so advertising was paid for by the money raised for the disaster fund. The lack of central funds to pay for the bills and ephemera are indicative of the limits of the UDC and suggest why they needed to fundraise as intensively as they did. The letter from the Gresford relief fund calling for help highlighted that a number of local authorities had already pledged assistance, and were simply waiting for permission from the Ministry of Health to use their municipal funds to aid others. ${ }^{57}$ The use of local funds for the relief of others was present after other disasters, and Richard Rodger's work on the 'common good' fund, at the disposal of the Edinburgh Town Council, shows that they donated a portion of it to external disaster funds, to encourage city residents to do the same. ${ }^{58}$ Increasing centralization during the interwar years meant that by the 1930 s, UDCs had little direct authority over unusual financial expenditure, and so were forced to appeal to the state to use funds in an unorthodox way. Instead of asking for existent funds to be used to aid a different local authority, especially given the economic climate in the South Wales coalfield during the early 1930s, the Barry UDC decided to use a proportion of the disaster funds they had raised to pay for advertisement.

The cost of advertising to encourage people to donate was a necessary one, as the Barry UDC relief funds were competing with other local and county-wide philanthropic schemes. Lynne Kiesling's work argues that, in the nineteenth century, locally based private charities, public relief funds and national charities coordinated their activities in order to provide relief for those in need. ${ }^{59}$ At a macro-level, this was ostensibly the case with the Barry UDC relief funds. They were part of a wide variety of charitable endeavours, which collectively raised vast sums for those in need. Yet, within Barry, there were tensions which pressured this small fund run by local government. Despite the positive response from residents, the nature of the UDC

\footnotetext{
${ }^{57}$ GA/BB/C/8/55. Wrexham (Gresford) Colliery Disaster Relief Fund to BUDCRF, 29 Sept. 1934.

${ }^{58}$ R. Rodger, 'The 'common good' and civic promotion: Edinburgh 1860-1914', in R. Colls and R. Rodger (eds.), Cities of Ideas: civil society and urban governance in Britain, 1800-2000 (Aldershot, 2004), 166.

${ }^{59}$ Kiesling, 'The long road to recovery', 236.
} 
relief funds meant that they faced severe competition for charitable giving both from smaller, more localized collections and from larger funds in nearby towns and cities.

Both the 1913 and the 1934 committees sent circulars to businesses asking them for donations to the fund, however, the 1913 fund (the letters returned to the 1934 fund do not seem to have been kept) was met with a lukewarm response. Theirs was not an unreasonable request: local businesses were expected to contribute to the local relief fund after a significant event, and a lack of involvement would be criticized. Barry Doyle's work has highlighted that, in Norwich, local businessmen accused their peers of insufficient involvement in philanthropic activity after a flood in $1912 .{ }^{60}$ Local businessmen only had to aid one fund, however, and so the responses of the business owners to the Barry UDC relief fund were somewhat blunt. The Chairman of the ship store merchants Frazer \& Co., who had their main offices at the Bute Docks in Cardiff, but their stores in Barry, sent a letter which simply read 'anything I do... at present, unless I change my mind, I intend to do at Cardiff.' ${ }^{\prime 61}$ The owners of Stephenson Brothers' Limited, household cleaning suppliers, sent a letter explaining that they had been at the opening of the Grocers' Exhibition in nearby Swansea, where Mr Fox-Andrews, President of the Grocers' Federation, had opened a fund, and so the company directors added their contribution to his list of subscribers. ${ }^{62}$ Some businesses were aware of the delicacy of the social ramifications of supporting one fund over another. A biscuit manufacturer, William Crawford \& Sons Ltd., wrote, 'although we do not doubt you would have preferred to see our name passing through your own list, we feel sure you will be pleased to know that our sympathy has been expressed in this tangible form. ${ }^{\prime 63}$ Poor timing, loyalty to larger towns and cities and a lack of local obligation led to many rejecting the UDC relief fund's request to subscribe to the Barry fund.

\footnotetext{
${ }^{60}$ B. Doyle, 'The structure of elite power in the early twentieth-century city: Norwich, 1900-35', Urban History, 24 (1997), 193-4.

${ }^{61} \mathrm{GA} / \mathrm{BB} / \mathrm{C} / 241$. J. L. Frazer to BUDCRF, 22 Oct. 1913.

62 GA/BB/C/241. Stephen Brothers' Limited to BUDCRF, 22 Oct. 1913.

${ }^{63} \mathrm{GA} / \mathrm{BB} / \mathrm{C} / 241$. William Crawford \& Sons Ltd. to BUDCRF , 24 Oct. 1913.
} 
A similar reluctance to engage with the efforts of the Barry UDC relief fund can be seen in the public responses to the 1913 collection efforts. Despite the popularity of the events among the residents of Barry, the 1913 fund received some criticism. One group of people who sold concert tickets for the relief fund was forced to postpone their own local concert, stating that it was due to 'the series of concerts + entertainments which have already been held in the town... as it was felt that the time was most inappropriate to secure good patronage. ${ }^{64}$ This was not an unusual complaint: donor fatigue was an emotion felt elsewhere after other disasters. In the North-East of England, after the West Stanley disaster in 1909, a whist drive was organized to raise funds for the families of the victims. A report of the event in the local newspaper reported that the attendance was low, suggesting that there had been too many whist drives organized over the previous weeks to make this one a success. ${ }^{65}$ The oversaturation of the entertainment market for a charitable cause was a fundraising hazard, and constituted a constant problem for those involved.

The charitable nature of the funds, with roots in ideas of voluntarism and civic society, naturally meant that the UDC called upon volunteers to help manage the collections. In 1913, the Boy Scouts were asked to deliver envelopes, to be filled with cash, alongside a leaflet explaining the reason for the collection. By 1934, instead of the Boy Scouts distributing the packets, various volunteers distributed leaflets in their districts and collected them again five days before the fundraising concert was held. ${ }^{66}$ The volunteers were organized by the Councillors of the wards the collections took place in. Many of the volunteers for the houseto-house collection in 1934 were women, but, among the men there were three Vicars and a Councillor, hinting at the type of middle class, civic-minded, volunteer the Councillor of the ward was likely to encounter.

While the volunteers seem to have enjoyed their experience overall, not all were pleased with the organization of the collections by the committee, especially in 1913. A man who offered to sell tickets for the 1913 variety show complained that the tickets he was supposed to sell

\footnotetext{
${ }^{64} \mathrm{GA} / \mathrm{BB} / \mathrm{C} / 241$. E. J. Chick \& S. Smith to BUDCRF, 10 Nov. 1913.

${ }^{65}$ DC, 26 Mar 1909, 12.

${ }^{66} \mathrm{GA} / \mathrm{BB} / \mathrm{C} / 8 / 55$. House-to-House Collection.
} 
for the concert were not delivered to him until two nights before the performance, resulting in a sale of only two. ${ }^{67}$ Other ticket sellers insisted that the house-to-house collection was responsible for the poor sale of concert tickets. In 1913 Mr Jenkins of the Barry Graving Dock and Engineering Co Ltd wrote to the fund stating that because of the collections that had already been made 'the men could really not afford it'. ${ }^{68}$ These criticisms seem to have been quietened by the more efficient organization of the later committee and no complaints were made, in writing, to the UDC in 1934.

This use of volunteers was married with an appeal to the citizens of Barry to aid their fellows as residents of South Wales. Throughout the interwar period, appeals to localism were key to the popularity of local government, but they also proved an important fundraising tactic, and local newspapers, posters and letters all played a role in encouraging citizens to donate to local causes. A leaflet written by Councillor Davies to accompany the 1913 house-to-house collection explained, 'I [Davies] feel sure that the Town of Barry, situate [sic] as it is in the same County as the bereaved district and linked with it being dependent upon the same trade, will desire to take its full share in the effort which is being made to relieve those who have been so suddenly plunged into sorrow and want. ${ }^{69}$ Not only did the appeals foster a sense of civic responsibility, but they could also be used to foster a sense of collective local identity. In the 1930s, this was especially needed in Barry, as the UDC was under some pressure to amalgamate with the much larger borough of Cardiff. From 1930 on there had been talk of an amalgamation, which simmered for a couple of years. ${ }^{70}$ By 1934 , this no longer seemed to be of immediate concern, however, the importance of appealing to local unity is important in understanding that while the UDC wanted to portray themselves as an urban entity: their existence relied on them doing so convincingly. While in 1913, alliance to the county superseded calls to town-based localism in the appeal for donations, by 1934 the town and its identity as a cohesive whole was central to the fundraising effort.

\footnotetext{
${ }^{67} \mathrm{GA} / \mathrm{BB} / \mathrm{C} / 241$. W. Evans to BUDCRF, 24 Nov. 1913.

$68 \mathrm{GA} / \mathrm{BB} / \mathrm{C} / 241$. D. Jenkins to BUDCRF, 17 Nov. 1913.

${ }^{69} \mathrm{GA} / \mathrm{BB} / \mathrm{C} / 241$. Leaflet, 22 Oct. 1913.

${ }^{70}$ Stead, 'The town that had come of Age', 404-6.
} 
In addition to calls for aid which appealed to notions of voluntarism and localism, there was a highly performative aspect of giving, illustrated through the lists of donors printed in the Barry press. In 1913, the Barry Dock News published lists of individual donors who gave generously to the house-to-house collection, only naming those who gave above 4 shillings. ${ }^{71}$ These types of printed newspaper subscription lists were common in the early twentieth century. Alex King notes that subscribers to local war memorial funds were encouraged to find their contributions in the newspapers, and that only publishing larger amounts of money, 'as bait' to incentivize donations was common. ${ }^{72}$ In Barry, only those who donated larger sums were named. Very few people chose to remain anonymous, and the lists of those who donated to the relief fund show both individuals and civic institutions, such as schools, churches and political clubs. ${ }^{73}$ By naming those who gave larger sums the committee highlighted the domination of the charitable market by those with an amount of disposable income throughout the 1913 collection.

So important were these published subscription lists that if there was a mistake, as in the case of the South Glamorgan Conservative \& Unionist Association's donation, amends were publicly printed. A rather concerned secretary for the Association wrote to the Barry UDC relief fund in 1913, asking them to make it clear in the local press that 'the sum was collected by the ladies' explaining that 'as it was inserted in the daily press it would appear that it was a sum they had contributed, whereas the fact is they simply placed their Organisation at the disposal of this good work' ${ }^{74}$ Their labour, in physically collecting the money, was key to understanding that their contribution was a significant one, attaching a social value to the work involved in their charitable donation. Their donation was collected by members of a local organisation, hinting at the rich associational culture of Barry, and the competition for donation that the town fund prompted. By encouraging these types of donations through the

\footnotetext{
${ }^{71} B D N, 14$ Nov 1913, 6.

${ }^{72}$ A. King, Memorials of the Great War in Britain: the symbolism and politics of remembrance (London, 1998), 32.

73 See, for example, BDN, 7 Nov. 1913, 2. For more on the anonymous donor see S. Flew, 'Unveiling the anonymous philanthropist: charity in the nineteenth century', Journal of Victorian Culture, 20 (2015), 20-33.

${ }^{74} \mathrm{GA} / \mathrm{BB} / \mathrm{C} / 241$. H.R. Topping to BUDCRF, 27 Oct. 1913.
} 
publication of collection amounts, the committee shows an awareness that associational culture could be merged with voluntarism to encourage civic engagement through the fund.

These mentions of philanthropic prowess were not confined to the local press, but also appeared in national newspapers. The 1934 Western Mail fund, to which the Barry UDC relief fund sent its collections, encouraged Welsh competition, publishing small reports of the town's successes, not only to encourage the residents of Barry, but to encourage other districts. ${ }^{75}$ This competition was not just in Wales, with The Times mentioning donations to the Mansion House fund from the 'Local appeal by Chairman of Weston-super-Mare U.D.C', the 'Local Appeal of Chairman of Slough U.D.C.' and the 'Local Appeal by Urban District Council of Enfield'. ${ }^{76}$ By 1934 the public donations of UDCs were visible on a national stage. This marks a considerable change from 1913, when only individual, business and newspaper donations to the Lord Mayors' Funds were published in the national press, not those by local authorities. ${ }^{77}$ In 1913 it seems that it was the norm for UDCs to donate their fund to a larger one without seeking national recognition, but by 1934 UDC relief funds were being recognized as independent contributions in their own right.

For all that the local news published the names of individual donors, in remembering the efforts of Barry, care was taken to ensure that no group were singled out. A draft of the thanks to be disseminated in newspapers after the committee had sent its last cheque to the Western Mail in 1934 made clear that the wording should include all, and that the Chairman of the Council 'desires to thank every helper who assisted towards making the collections a success. It would be invidious to name any particular person as all classes rendered invaluable services in many directions. ${ }^{178}$ The constructed legacy of the Barry UDC relief fund was one of cooperation and class cohesion. By presenting the fundraising efforts in this way, the middle class bias present throughout both fundraising campaigns, through the makeup of the

\footnotetext{
${ }^{75} \mathrm{GA} / \mathrm{BB} / \mathrm{C} / 8 / 55$. Western Mail \& South Wales Echo to BUDCRF, 2 Nov. 1934.

76 TT, 12 Dec 1934, 4.

${ }^{77}$ For instance, see TT, 7 Nov. 1913, 3; 3 Dec. 1913, 6.

${ }^{78} \mathrm{GA} / \mathrm{BB} / 8 / \mathrm{C} / 55$. Sixth and Final List of Subscriptions.
} 
volunteers and committee members was, on paper, eradicated, and the residents of Barry portrayed as a single entity working towards a common cause.

\section{Conclusion}

For all that reporting in various newspapers, both local and national, provided an homogenous account which extolled the virtues of the various funds raised in response to disaster, the UDC funds reveal some of the intricacies of charitable giving and local governance in the early twentieth century. If the 1913 relief fund saw the Barry UDC struggle to meaningfully engage with local businesses, the 1934 committee democratically appealed to the residents of Barry to ensure the fund had a broad support base. By the 1930s, UDC funds were nationally recognised through inclusion in press reports. This recognition of the administrative power of the UDCs, at a time when their autonomy was rescinding, was an important indication of the national recognition UDCs were attempting to foster at both a local and national level.

The pressures which the Barry UDC relief funds faced were broadly representative of other UDCs who also decided to raise local town funds for the families of disaster victims. UDC relief funds were highly popular as a philanthropic response to disaster. They allowed the town to unify through a common goal, express solidarity with those in need, and provided a means through which the Council could express its civic pride. The funds were direct interjection into what was previously the realm of charity, and, when the disaster fund had been completed, the Barry UDC withdrew itself from the area of civic society which it had invaded. This careful manoeuvring through the porous line between local government and civic society suggests that the UDC was only able to overstep this unspoken and blurred boundary at times of perceived need. Yet, although this was a subtle interplay between strong civic forces, in general the residents of Barry did not seem to mind this intervention overly much. In October 1913 the Barry Dock News proudly proclaimed that 'Barry has not been behind in doing its share'.$^{79}$ The residents of Barry they had supported fellows in need, fulfilling their civic and

\footnotetext{
${ }^{79}$ BDN, 31 Oct. 1913, 5.
} 
moral duty, and could be rest assured that, were the situation to be reversed, they too would be offered support from a similarly minded public. 